\author{
Research Article \\ www.ijrap.net (ISSN:2229-3566)
}

\title{
ROLE OF GUDUCHI TINOSPORA CORDIFOLIA (WILLD) MIERS. IN COUNTERACTING THE ADVERSE DRUG REACTIONS INDUCED BY ANTIDEPRESSANT DRUGS
}

\author{
Mamatha Sri $\mathrm{S}^{1 *}$, K.S. Jayashree ${ }^{2}$ \\ ${ }^{1}$ Associate Professor, Department of Dravyaguna, Government Ayurveda Medical College and Hospital, \\ Bangalore, Karnataka, India \\ ${ }^{2}$ Former Professor and HOD, Department of Dravyaguna, Government Ayurveda Medical College and Hospital, \\ Bangalore, Karnataka, India.
}

Received on: 03/03/21 Accepted on: 22/04/21

\begin{abstract}
*Corresponding author
E-mail: mamathasri.ayu@gmail.com
\end{abstract}

DOI: $10.7897 / 2277-4343.120367$

\begin{abstract}
In the present scenario psychosomatic stressful situation is been increasing which has resulted in increased incidence in Psychiatric disorders. The prevalence of all mental disorders was observed to be 65.4 per 1000 population. In 2017, 197.3 million people had mental disorders in India, including 45.7 million with depressive disorders and 44.9 million with anxiety disorders. Depression and other mood disorders need long term treatment. Among antidepressants SSRI group of drugs are more frequently advocated followed by Tricyclics. Due to long term medications, patients often complaints of adverse drug reactions which many times leads to discontinuation of treatment. In this study Guduchi was chosen to address the ADRs induced by antidepressant drugs at GI level. It was a randomized single blind comparative clinical study, where 40 volunteers undergoing antidepressant treatment and have developed ADRs were selected. Subjects were randomly assigned into two group A and B with 20 patients each. Guduchi Rasakriya 1 gram in divided dose was given to group A and symptomatic conventional treatment to group B. It was observed that Guduchi was effective in major number of problems raised in GIT like Dryness of mouth, Gastric irritation, Nausea, Anorexia, Loose stools. In this clinical study Guduchi ghanasara (rasakriya) exhibited significant response in adverse drug reactions at the level of GIT induced by Antidepressant drugs (SSRI and Tricyclics) when compared to conventional symptomatic treatment.
\end{abstract}

Keywords: Guduchi, Tinospora cordifolia, Adverse drug reactions, Antidepressant drugs, SSRI.

\section{INTRODUCTION}

Mental disorders are raising in an alarming rate with significant impact on health. According to WHO the prevalence of mental disorders (depression, anxiety, post-traumatic stress disorder, bipolar disorder and schizophrenia) was $22.1 \%$ at any point in time in the conflict-affected population. ${ }^{1}$ Depression is a common mental disorder and one of the main causes of disability worldwide. Globally an estimated 264 million people are affected by depression. ${ }^{2}$

It is seen commonly among women than men, with female/male risk ratios roughly $2: 1 .^{3}$ Most of the Antidepressant drugs are likely to produce a wide range of adverse drug reaction on different systems like Dryness of mouth, Constipation, Tachycardia, Delayed ejaculation, Postural hypotension etc. according to WHO statistics (census 2001) 24\% of male and 26\% of female develop ADR. Among the Antidepressants Selective Serotonin Reuptake Inhibitor (SSRI) are more commonly advocated as they are safer than Tricyclics with less sedative and fewer cardiovascular effects. Still, they also produce certain ADR's, more frequently reported are Nausea, Dryness of mouth, Vomiting, Anorexia, Constipation, Gastric irritation, Loose stools concerned to GIT. ${ }^{4}$ Administration of Antidepressant drug is needed to manage depression but their ADR's need an effective and safer management as well. In conventional system each ADR is treated with separate drug, while a single herb with multifarious pharmacological activities can be used to manage many symptoms. Guduchi botanically identified as Tinospora cordifolia (Willd) Miers is one of the promising drugs. The present study was carried out to evaluate the counteracting effect of Guduchi in Adverse drug reactions induced by antidepressant drugs.

\section{MATERIAL AND METHODS}

The study was a randomized single blind comparative clinical trial. Subjects were randomly selected and recruited in two groups. 40 subjects who were under Antidepressant drugs (SSRIs and Tricyclic) and had developed ADRs at the level of GIT were registered and categorized into two groups A and B. Institutional ethical clearance was taken and the study was carried out after taking consent from the patients. This trail was done as per international conference of Harmonization-Good Clinical practices Guidelines (ICH-GCP).

Examination: Patients were subjected to a detail clinical examination according to the format framed for the purpose. 
Table 1: Study design

\begin{tabular}{|c|c|c|c|c|c|c|}
\hline Group & $\begin{array}{c}\text { No of } \\
\text { Volunteers }\end{array}$ & Drug & Dosage & Vehicle & Time & Duration \\
\hline $\mathrm{A}$ & 20 & $\begin{array}{l}\text { Guduchi Ghana Sara and } \\
\text { Antidepressant drug }\end{array}$ & $\begin{array}{c}1 \text { gram of Ghana Sara in } \\
\text { divided dose }\end{array}$ & Water & $\begin{array}{l}\text { Morning and } \\
\text { Evening }\end{array}$ & 1 Month \\
\hline B & 20 & $\begin{array}{l}\text { Antidepressant drug and symptomatic } \\
\text { conventional treatment }\end{array}$ & & Water & & 1 Month \\
\hline
\end{tabular}

Table 2: Assessment of response: Assessment was made on $0^{\text {th }}$ day, $15^{\text {th }}$ day and $30^{\text {th }}$ day of treatment for the symptoms at the level of GIT based on following points

\begin{tabular}{|c|c|}
\hline 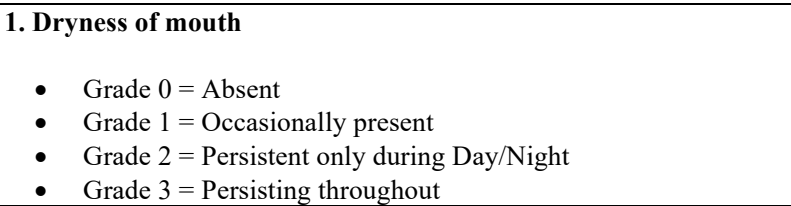 & $\begin{array}{l}\text { 2. Nausea } \\
\text { - } \quad \text { Grade } 0=\text { Absent } \\
\text { - } \quad \text { Grade } 1=\text { Occasionally present } \\
\text { - } \quad \text { Grade } 2=\text { Daily on and off } \\
\text { - } \quad \text { Grade } 3=\text { Continuous }\end{array}$ \\
\hline $\begin{array}{l}\text { 3. Vomiting } \\
\text { - } \quad \text { Grade } 0=\text { Absent } \\
\text { - } \quad \text { Grade } 1=\text { Occasionally present } \\
\text { - } \quad \text { Grade } 2=\text { Once daily } \\
\text { - Grade } 3=\text { More than once per day }\end{array}$ & $\begin{array}{l}\text { 4. Anorexia } \\
\text { - Grade } 0=\text { Normal appetite } \\
\text { - } \quad \text { Grade } 1=\text { Not much altered, can consume food, occasional } \\
\text { hunger } \\
\text { - } \text { Grade } 2=\text { Reduced hunger, can accept food once a day. } \\
\text { - Grade } 3=\text { No appetite, does not relish food, consumption is } \\
\text { markedly reduced. }\end{array}$ \\
\hline $\begin{array}{l}\text { 5. Gastric irritation } \\
\text { - Grande } 0=\text { Absent } \\
\text { - Grade } 1=\text { Occasionally present } \\
\text { - Grade } 2=\text { Aggravates after consumption of coffee/tea/others, } \\
\text { increases when food intake is delayed. } \\
\text { Grade } 3=\text { Persisting always, irrespective of hunger and food } \\
\text { taken. }\end{array}$ & $\begin{array}{l}\text { 6. Constipation } \\
\text { - } \quad \text { Grade } 0=\text { Normal-once daily } \\
\text { - } \quad \text { Grade } 1=\text { Alternate days } \\
\text { - } \quad \text { Grade } 2=\text { Once in } 3 \text { days } \\
\text { - } \quad \text { Grade } 3=\text { Once in } 4 \text { days and above }\end{array}$ \\
\hline $\begin{array}{l}\text { 7. Loose stools } \\
\begin{aligned} \text { - } & \text { Grade } 0=\text { Normal-once daily } \\
\text { - } & \text { Grade } 1=2-3 \text { times a day, frequently increased } \\
\text { - } & \text { Grade } 2=4-6 \text { times a day, quantity not altered } \\
\text { - } & \text { Grade } 3=\text { More than } 6 \text { times/day }\end{aligned}\end{array}$ & $\begin{array}{l}\text { Results } \\
\qquad \begin{aligned} 0 & =\text { Good } \\
1 & =\text { Moderate } \\
2 & =\text { Mild } \\
3 & =\text { No response }\end{aligned}\end{array}$ \\
\hline
\end{tabular}

\section{RESULT}

Physico-chemical analysis of Guduchi churna confirmed that the drug taken for the clinical trial was in accordance with the values given in Ayurvedic pharmacopoeia of India. Phytochemical analysis of Guduchi shows the presence of Alkaloid, Sugar, Saponin and Volatile oil. Rasakriya (ghanasara) shows the presence of Alkaloids, Saponins, Bitter principles and also volatile principles.

TLC of Guduchi Ghanasara and Guduchi churna: Two major spots bluish violet at $\mathrm{Rf}$ value 0.42 and brownish yellow at $\mathrm{Rf}$ value 0.56 are visible.

Table 3: Rf value of TLC

\begin{tabular}{|c|c|}
\hline Sample & Rf value \\
\hline Guduchi Churna & 0.42 and 0.56 \\
\hline Guduchi Ghanasara & 0.42 and 0.56 \\
\hline
\end{tabular}

\section{Clinical study}

Out of 40 subjects selected 12 falls under the age group between 21-30 years, 10 falls in the age group between 31-40 years and 18 falls in the age group between $41-50$ years. $65 \%$ (26) of volunteers were females in both the group while $35 \%$ (14) constituted men. 35 were married and 5 unmarried. 70\% (28) volunteers were from urban and 30\% (12) were from rural background. The observation shows 35 volunteers were Hindu and 5 were Muslims. 5 volunteers were illiterate and 10 were having high school education while 25 had collegiate education. $55 \%$ (22) were house wives, $25 \%$ (10) were physical labors, $10 \%$ (4) were doing desk work, $7.5 \%$ (3) were students and $2.5 \%$ (1) was unemployed. Maximum of volunteers comes under middle income $(85 \%)$ and $15 \%$ from low income. The present study shows $65 \%$ (26) could be categorized under vata-pitta prakriti, $27.5 \%$ (11) under pitta-kaphaja prakriti and 7.5\% (3) under vatakaphaja prakriti.

\section{Statistical analysis}

The data collected in this study is analyzed by computing descriptive statistics namely mean, standard deviation and $95 \%$ confidence interval where ever necessary. The quantitative variables are compared with in the groups using a non-parametric test namely Friedman test from $0^{\text {th }}$ day to $30^{\text {th }}$ day and value is given as Chi square value. Between the group comparison of qualitative variables is done using non-parametric test namely Mann-Whitney U test. Since for large samples Mann-Whitney U test converges to standard normal test, the values are given as ' $\mathrm{z}$ test'. The ' $p$ ' value obtained here is considered statistically significant whenever $\mathrm{p} \leq 0.05$ 
Statistical inference for within group comparison using Friedman test

Table 4: Statistical inference for within group comparison using Friedman test

\begin{tabular}{|c|c|c|c|c|c|c|c|c|}
\hline & \multicolumn{2}{|c|}{ Group A } & \multicolumn{5}{c|}{ Group B } \\
\hline Symptoms & No of subjects & Chi-square & df & P-value & No. of subjects & Chi-square & df & P-value \\
\hline Dryness of mouth & 13 & 22.80 & 2 & $<0.0001$ & 16 & 9.33 & 2 & $<0.009$ \\
\hline Constipation & 6 & 7.60 & 2 & $<0.022$ & 6 & 3.714 & 2 & $>0.156$ \\
\hline Gastric irritation & 5 & 6.615 & 2 & $>0.37$ & 7 & 4.467 & 2 & $>0.097$ \\
\hline Nausea & 8 & 14.857 & 2 & $<0.001$ & 3 & 4.0 & 2 & $>0.135$ \\
\hline Vomiting & 3 & 4.667 & 2 & $>0.097$ & \multicolumn{2}{|c|}{ Analysis not possible due to small sample } \\
\hline
\end{tabular}

Statistical inference for between group comparison using Mann-Whitney U-test

Table 5: Statistical analysis for between the group on $0^{\text {th }} \mathrm{day}, 15^{\text {th }} \mathrm{day}, \mathbf{3 0}^{\text {th }}$ day with respect to Dryness of mouth (Asyashosha)

\begin{tabular}{|c|c|c|c|c|c|}
\hline Dryness of mouth & Group A & Group B & Total & Z- test & p -value \\
\hline \multicolumn{6}{|c|}{ Day 0} \\
\hline 0 & - & - & - & \multirow[t]{4}{*}{0.118} & \multirow{4}{*}{$>0.906$} \\
\hline 1 & 1 & - & 1 & & \\
\hline 2 & 6 & 9 & 15 & & \\
\hline 3 & 7 & 7 & 14 & & \\
\hline Total & 14 & 16 & 30 & & \\
\hline \multicolumn{6}{|c|}{ Day 15} \\
\hline 0 & 3 & - & 3 & \multirow[t]{4}{*}{3.233} & \multirow[t]{4}{*}{$<0.001$} \\
\hline 1 & 7 & 2 & 9 & & \\
\hline 2 & 3 & 8 & 11 & & \\
\hline 3 & 1 & 6 & 7 & & \\
\hline Total & 14 & 16 & 30 & & \\
\hline \multicolumn{6}{|c|}{ Day 30} \\
\hline 0 & 8 & 2 & 10 & \multirow[t]{4}{*}{3.488} & \multirow[t]{4}{*}{$<0.004$} \\
\hline 1 & 4 & 2 & 6 & & \\
\hline 2 & 1 & 7 & 8 & & \\
\hline 3 & - & 5 & 5 & & \\
\hline Total & 13 & 16 & 29 & & \\
\hline
\end{tabular}

Table 6: Statistical analysis for between the group on $0^{\text {th }} d a y, 15^{\text {th }}$ day, $30^{\text {th }}$ day with respect to Constipation (Vitsanga)

\begin{tabular}{|c|c|c|c|c|c|}
\hline Constipation & Group A & Group B & Total & Z-test & P-value \\
\hline \multicolumn{6}{|c|}{ Day 0} \\
\hline 0 & - & - & - & \multirow[t]{3}{*}{1.010} & \multirow[t]{3}{*}{$>0.312$} \\
\hline 2 & 6 & 1 & 7 & & \\
\hline 3 & 2 & 4 & 6 & & \\
\hline Total & 8 & 6 & 14 & & \\
\hline \multicolumn{6}{|c|}{ Day 15} \\
\hline 0 & - & - & - & \multirow[t]{5}{*}{0.889} & \multirow[t]{5}{*}{$>0.374$} \\
\hline 1 & 3 & 2 & 5 & & \\
\hline 2 & 4 & 1 & 5 & & \\
\hline 3 & 1 & 3 & 4 & & \\
\hline Total & 8 & 6 & 14 & & \\
\hline \multicolumn{6}{|c|}{ Day 30} \\
\hline 0 & - & 1 & 1 & \multirow[t]{4}{*}{0.763} & \multirow[t]{4}{*}{$>0.445$} \\
\hline 1 & 3 & 1 & 4 & & \\
\hline 2 & 3 & 2 & 5 & & \\
\hline 3 & & 2 & 2 & & \\
\hline Total & 6 & 6 & 12 & & \\
\hline
\end{tabular}

Table 7: Statistical analysis for between the group on $0^{\text {th }}$ day, $15^{\text {th }}$ day, $30^{\text {th }}$ day with respect Gastric irritation (Amlapitta)

\begin{tabular}{|c|c|c|c|c|c|}
\hline Gastric irritation & Group A & Group B & Total & Chi-square & P-value \\
\hline \multicolumn{6}{|c|}{ Day 0 } \\
\hline 0 & - & - & & \multirow[t]{4}{*}{1.972} & \multirow[t]{4}{*}{$<0.049$} \\
\hline 1 & 2 & - & 2 & & \\
\hline 2 & 2 & 1 & 3 & & \\
\hline 3 & 2 & 6 & 8 & & \\
\hline Total & 6 & 7 & 13 & & \\
\hline \multicolumn{6}{|c|}{ Day 15} \\
\hline 0 & - & - & & & \\
\hline 1 & 4 & 1 & 5 & \multirow[t]{4}{*}{2.248} & \multirow[t]{4}{*}{$<0.025$} \\
\hline 2 & 1 & & 1 & & \\
\hline 3 & 1 & 6 & 7 & & \\
\hline Total & 6 & 7 & 13 & & \\
\hline
\end{tabular}


Mamatha Sri S and K. S. Jayashree / Int. J. Res. Ayurveda Pharm. 12 (3), 2021

\begin{tabular}{|c|c|c|c|c|c|}
\hline \multicolumn{7}{|c|}{ Day 30 } & \multirow{2}{*}{2.521} & $<0.012$ \\
\hline 0 & 3 & - & 3 & & \\
\hline 2 & 1 & 1 & 2 & & \\
\hline 3 & 1 & 2 & 3 & & \\
\hline Total & - & 4 & 4 & & \\
\hline
\end{tabular}

Table 8: Statistical analysis for between the group on $0^{\text {th }}$ day, $15^{\text {th }}$ day, $30^{\text {th }}$ day with respect Nausea (Hrullasa)

\begin{tabular}{|c|c|c|c|}
\hline Adverse Drug Reactions & Group A & Group B & Total \\
\hline 0 & - & - & - \\
\hline 1 & 3 & 3 & 6 \\
\hline 2 & 1 & - & 1 \\
\hline 3 & 4 & - & 4 \\
\hline Total & $\mathbf{8}$ & $\mathbf{3}$ & $\mathbf{1 1}$ \\
\hline 0 & 4 & 2 & 6 \\
\hline 1 & 2 & 1 & 3 \\
\hline 2 & 2 & - & 2 \\
\hline 3 & - & - & - \\
\hline Total & $\mathbf{8}$ & $\mathbf{3}$ & $\mathbf{1 1}$ \\
\hline 0 & 7 & 2 & 9 \\
\hline 1 & 1 & 1 & 2 \\
\hline 2 & - & - & - \\
\hline 3 & - & - & - \\
\hline Total & $\mathbf{8}$ & $\mathbf{3}$ & $\mathbf{1 1}$ \\
\hline
\end{tabular}

Table 9: Statistical analysis for between the group on $0^{\text {th }}$ day, $15^{\text {th }}$ day, $30^{\text {th }}$ day with respect Vomiting (Chardi)

\begin{tabular}{|c|c|c|c|}
\hline Adverse Drug Reactions & Group A & Group B & Total \\
\hline & \multicolumn{3}{|c|}{ Day 0 } \\
\hline 0 & - & - & - \\
\hline 1 & 3 & - & 3 \\
\hline 3 & - & 1 & 1 \\
\hline Total & $\mathbf{3}$ & $\mathbf{1}$ & $\mathbf{4}$ \\
\hline & \multicolumn{4}{|c|}{ Day 15 } \\
\hline 0 & 2 & - & 2 \\
\hline 1 & 1 & 1 & 2 \\
\hline 3 & - & - & - \\
\hline Total & $\mathbf{3}$ & $\mathbf{1}$ & $\mathbf{4}$ \\
\hline & \multicolumn{4}{|c|}{ Day 30 } \\
\hline 0 & 3 & - & 3 \\
\hline 1 & - & 1 & 1 \\
\hline 3 & - & - & - \\
\hline Total & $\mathbf{3}$ & $\mathbf{1}$ & $\mathbf{4}$ \\
\hline
\end{tabular}

Table 10: Statistical analysis for between the group on $0^{\text {th }}$ day, $15^{\text {th }}$ day, $30^{\text {th }}$ day with respect Anorexia (Aruchi)

\begin{tabular}{|c|c|c|c|}
\hline Adverse Drug Reactions & Group A & Group B & Total \\
\hline & \multicolumn{3}{|c|}{ Day 0 } \\
\hline 0 & - & - & - \\
\hline 1 & 2 & 1 & 3 \\
\hline Total & $\mathbf{2}$ & $\mathbf{1}$ & $\mathbf{3}$ \\
\hline & \multicolumn{4}{|c|}{ Day 15 } \\
\hline 0 & - & - & - \\
\hline 1 & 2 & 1 & 3 \\
\hline Total & $\mathbf{2}$ & $\mathbf{1}$ & $\mathbf{3}$ \\
\hline & \multicolumn{4}{|c|}{ Day 30 } \\
\hline 0 & 1 & 1 & 2 \\
\hline 1 & 1 & - & 1 \\
\hline Total & $\mathbf{2}$ & $\mathbf{1}$ & $\mathbf{3}$ \\
\hline
\end{tabular}

Table 11: The overall result

\begin{tabular}{|c|c|c|c|c|}
\hline Symptoms & No. of subjects & Chi-square & df & p-value \\
\hline Dryness of mouth & 29 & 31.524 & 2 & $<0.0001$ \\
\hline Constipation & 12 & 11.273 & 2 & $<0.0001$ \\
\hline Gastric irritation & 12 & 1.273 & 2 & $<0.0001$ \\
\hline Nausea & 11 & 18.58 & 2 & $<0.0001$ \\
\hline
\end{tabular}




\section{DISCUSSION}

The present study was aimed at evaluating the counteracting effects of Guduchi (Tinospora cordifolia) in Adverse drug reaction (related to GIT) induced by Antidepressant drugs. SSRI group of drugs are therapeutically indicated in some of the specific psychiatric disorders like Major Depressive disorder, social anxiety disorder, OCD, Bulimia nervosa, Premenstrual dysphonic disorder, generalized anxiety disorder, post-traumatic stress disorder etc. ${ }^{5}$ Significant side effects of antidepressants are common. Though adverse events are lower in SSRI group of drugs when compared to Tricyclics and Tetracyclic drugs still, some of the adverse effects are frequently reported in SSRI group of antidepressants. Increased synaptic availability of serotonin stimulates a large number of post synaptic 5-HT receptor types which is suspected to contribute to common adverse effects characteristics of this class of drugs, including gastrointestinal (nausea, vomiting) and sexual effects (delayed or impaired orgasm). ${ }^{6}$ The major system affected by SSRIs is gastro intestinal tract. Common ADR's produced by these drugs are Dryness of mouth, Nausea, Vomiting, Anorexia, Gastric irritation, Diarrhea, Constipation etc.

The definition of Bheshaja and Abheshaja suggests the emphasis given to ADR in Ayurveda literature and this is one of the reasons for the ancient scholars to stress on the importance of samskara. ADRs are common in synthetic drugs which contain single chemical entity without a counteracting factor in it. Guduchi is effective in major number of problems raised in GIT, thus the problem and solution selected for the study appears to be appropriate. To make the drug more acceptable and palatable for a psychologically disturbed patient capsules filled with Guduchi rasakriya was administered.

Significant improvement was seen in subjects presented the symptom of Dryness of mouth while the conventional treatment did not show any improvement. Pharmacological activities of Guduchi like trishnanigrahana ${ }^{7}$ and vata-pittahara property might have helped in relieving thirst (Trishna). Clinically the result was highly significant for Nausea (Hrillasa). The presence of saponin in Guduchi might have helped in improving gastric secretion there by relieves nausea (Hrillasa). Clinically highly significant response was found in subjects complaining of Vomiting. Guduchi is found to be an effective chardinigrahanadravya ${ }^{8}$, also the presence of alkaloids may be responsible for antispasmodic and smooth muscle relaxing activity ${ }^{9}$. Among volunteers with gastric irritation (Amlapitta) significant result was found in Group A and no response in Group B. Guduchi has better effect in relieving gastric irritation, it is a deepanadravya ${ }^{10}$ and proved for antiulcerogenic activity. Guduchi might have balanced the gastric secretion in order to prevent irritation and improve digestion. Significant results were seen in subjects presenting with Anorexia (Aruchi) in Group A. Tiktharasa ${ }^{11}$ is known for ruchya property and deepana property. Saponin content in the drug may also be responsible to improve digestion. Loose stool was seen in Group A which showed significant results. Guduchi with Sangrahi ${ }^{12}$ property and also as rasakriya exhibited Kashaya rasa, this might be responsible for stambana action. This may be also due to antagonistic effects of agonists such as 5-HT. Statistically significant results were not seen in the above symptoms as the number of subjects presenting with different symptoms were less and not uniform. The attributes of Guduchi in total has tiktha, kashaya rasa, madhuravipaka, ushnaveerya and laghuguna ${ }^{13}$. It is included in Tripthighna ${ }^{14}$, Trishnanigraha mahakashaya of Charaka and Guduchyadi, Aragwadadi, Patoladigana of Sushrutha which have potential to pacify Trishna, Hrullasa, Chardi, Aruchi, Atisara etc. Guduchi is also attributed with wide range of activities like Deepana, Panchana, Sangrahi, Trishnanigrahana, Chardihara, Vitbheda etc. All these properties appear to be effective even in ADRs produced by psychotropic drugs especially SSRIs and Tricyclics. Serotonin appears to be functional component of GIT which is influenced by vata and Guduchi being tridoshashamaka has helped in combating the serotonin effect in GIT. Irrespective of nidana Guduchi can exhibit therapeutic efficacy compared to conventional treatment in which every GIT feature should be treated separately. Though it was out of frame work of this study ten days after the completion of the course of treatment when reviewed 9 subjects expressed a feeling of wellbeing, more energetic and more active. This can be compared to Rasayana (Adaptogen) activity of Guduchi $^{15}$, also few subjects who had Mutradaha and Sheetapitta were also totally relieved from these symptoms. This may be because of wide spectrum activity of Pramehara, Mutrala and Kushtaghna activity of Guduchi.

\section{CONCLUSION}

This clinical trial shows that Guduchi is an effective drug in counteracting ADR produced by SSRI and Tricyclic group of Antidepressant drugs at the level of GIT like Dryness of mouth (Asyashosha), Nausea (Hrullasa), Vomiting (Chardi), Loose stools (Atisara), Gastritis (Amlapitta), while symptom specific drugs are administered in conventional medicine, Guduchi alone with its multitudinous attributes is effective in GIT related ADRs produced by SSRI and Tricyclic group of drugs. The effect of Ghanasara (Rasakriya) in relieving Constipation is not encouraging. Guduchi being a Rasayana is effective in exhibiting over all well- being of the individual. Further, opening the arena for more research on Guduchi for ADRs induced by antidepressant drugs on other systems and also as supportive therapy with Antidepressants because Guduchi has been proved for Antistress activity as well.

\section{REFERENCES}

1. Fiona charlson, Mark van Ommeren, Abraham Flaxman et al. New WHO Prevalence estimates of mental disorders in conflict settings: a systematic review and meta-analysis. The lancet July 20, 2019; 394(10194): 240-248. [cited on 2021 April 17]. Available from: https://www.thelancet.com

2. Spencer L James, Degu Abate, Kalkidan Hassen Abate et al. Global, regional, and national incidence, prevalence, and years lived with disability for 354 diseases and injuries for 195 countries and territories, 1990-2017: a systematic analysis for Global Burden of Disease study 2017, The Lancet Nov 2018; 392(10159): 1789-858. [cited on 2021 April 18]. Available from: https://www.thelancet.com

3. Ronald C Kessler, Epidemiology of Women and Depression, Journal of Affective Disorders, March 2003; 74(1): 5-13. [cited on 2021 February 11]. Available from: https://www.journals.elsevier.com

4. Benjamin James Sadock, Virginia Alcott Sadock, Pedro Ruiz, Kaplan \& Sadock's Synopsis of Psychiatry Behavioural Sciences/Clinical Psychiatry, Selective Serotonin Reuptake Inhibitors, Eleventh Edition, New York, Wolters Kluwer; 2015. p. 3639.

5. Benjamin James Sadock, Virginia Alcott Sadock, Pedro Ruiz, Kaplan \& Sadock's Synopsis of Psychiatry Behavioural Sciences/Clinical Psychiatry, Selective Serotonin Reuptake Inhibitors, Eleventh Edition, New York, Wolters Kluwer; 2015. p. 3625.

6. Hardman, Limbird Gilman, Goodman and Gilman's The Pharmacological Basis of Therapeutics, $10^{\text {th }}$ edition, New 
York, Mc Graw-Hill Medical Publishing division; 2001. p 459-461.

7. Agnivesha, Charaka Samhita Text with English translation by Vaidya Bhagavan Das based on Chakrapani Datta's Ayurveda Dipika, Sutra sthana $4 / 29,5^{\text {th }}$ edition, Varanasi; Chaukhambha Orientalia; 1997.p. 95.

8. Kaiyadeva, Kaiyadeva Nighantu (Pathyapathya Vibodhakh) Edited and Translated by Prof. Priyavrata Sharma and Dr. Guruprasad Sharma, Aushadhi varga 9/10, Varanasi, Chaukhambha Orientalia; 1979. p. 5.

9. Sharma P C, Yelne M.B, Dennis T J. Database of Medicinal Plants Used in Ayurveda, Vol III, New Delhi, CCARS Publication; 2005. p. 321-353.

10. Agnivesha, Charaka Samhitha A Text with English translation by Vaidya Bhagavan Das based on Chakrapani Datta's Ayurveda Dipika, Sutra sthana $25 / 40,5^{\text {th }}$ edition, Varanasi, Chaukhambha Orientalia; 1997. p. 426.

11. Narahari Pandit, Raja Nighantu with Dravyaguna Prakasika Hindi Commentary by Dr. Indradeva Tripathi, Guduchyadi varga 13-17, Varanasi, Chaukhambha Orientalia; 2003. p. 3031.
12. Dhanwantari Nighantu, edited by Prof. Priyavrata Sharma translated by Dr. Guruprasad Sharma, Guduchyadi varga 5-7, $2^{\text {nd }}$ Edition, Varanasi, Chaukhambha Orientalia; 1998. p. 17.

13. Sri Bhavamishra, Bhavaprakasa Nighantu, Commentary by Dr. K. C. Chunekar, Guduchyadi varga 8-10, Varanasi, Chaukhambha Bharati Academy; 2004. p. 269.

14. Agnivesha, Charaka Samhita Text with English translation by Vaidya Bhagavan Das based on Chakrapani Datta's Ayurveda Dipika, Sutra sthana $4 / 11,5^{\text {th }}$ edition, Varanasi, Chaukhambha Orientalia; 1997. p. 90.

15. Nirmala N Rege, Urmila M Thatte, Sharadini A Dahanukar. Adaoptogenic properties of six rasayana herbs used in Ayurvedic medicine, Phytotherapy Research 1999; 13(4): 275-291. [Cited on 2021 February 11]. Available from: https://onlinelibrary.wiley.com

\section{Cite this article as:}

Mamatha Sri S and K.S. Jayashree. Role of Guduchi Tinospora cordifolia (Willd) Miers. In counteracting the adverse drug reactions induced by antidepressant drugs. Int. J. Res. Ayurveda Pharm. 2021;12(3):25-30 http://dx.doi.org/10.7897/22774343.120367 